10IKC-229

\title{
PHOSCORITES FROM THE SALITRE ALKALINE COMPLEX, BRAZIL: ORIGIN AND PETROGENETIC IMPLICATIONS
}

\author{
Barbosa* ESR ${ }^{1,2}$, Brod JA ${ }^{1,2,3}$, Junqueira-Brod TC ${ }^{1,3}$, Cordeiro PFO ${ }^{2,3}$, Santos RV ${ }^{2,3}$, Dantas EL ${ }^{2,3}$ \\ 1-Instituto de Estudos Sócio-Ambientais, Universidade Federal de Goiás, Goiânia, Brazil, elisa.barbosa@uol.com.br \\ 2-Instituto de Geociências, Universidade de Brasília, Brasília, Brazil \\ 3-Conselho Nacional de Desenvolvimento Cientifico e Tecnológico, Brasília, Brazil
}

\section{INTRODUCTION}

The Alto Paranaíba Igneous Province (APIP), in central Brazil, is a key area for the study of phoscorites and related rocks, not only for the amount of alkaline-carbonatite complexes, but also for the diversity of lithotypes and variable stages of metassomatism in each complex. In this context, the Salitre complex was chosen for this study because it concentrates a large diversity of rocks preserved from metassomatic alteration, allowing the observation of preserved magmatic textures and their relationships.

In this work we use petrographic, mineral chemistry, wholerock geochemistry, stable isotopes $(\mathrm{C}, \mathrm{O})$ and $\mathrm{Sr}-\mathrm{Nd}$ isotope data to characterize well-preserved phoscorites and to investigate their origin and magmatic evolution.

The Salitre alkaline-carbonatite-phoscorite complex is part of the Alto Paranaíba Igneous Province, and consists of three separate bodies. Salitre I is a central, kidney-shaped body composed of two coalescing intrusions. One occupies the northern portion, comprising dominantly perovskite bebedourites (B1), with swarms of ring dykes of carbonatites and phoscorites; the other is located in the southern portion and contains melanite bebedourites (B2). Salitre II and III are bebedourite-dominated smaller intrusions, respectively to the north and to the south of Salitre I.

\section{PETROGRAPHY}

Texturally and structurally, phoscorites vary from fine- to coarse-grained, locally pegmatoidal, and may occur both as breccia and as banded rocks. Phoscorites also show ductile deformation that suggests a crystal mush movement. Metassomatic zones, varying from few milimeters to many meters are common, associated with carbonatite veins.

Two types of phoscorite occur in Salitre I, as shown in Figure 1: P1 phoscorites contain essential olivine, phlogopite and apatite, with accessory magnetite and traces of perovskite; P2 phoscorites are composed of the same essential phases, but also contain carbonate-rich pockets, accessory pyrochlore and rare phlogopite.

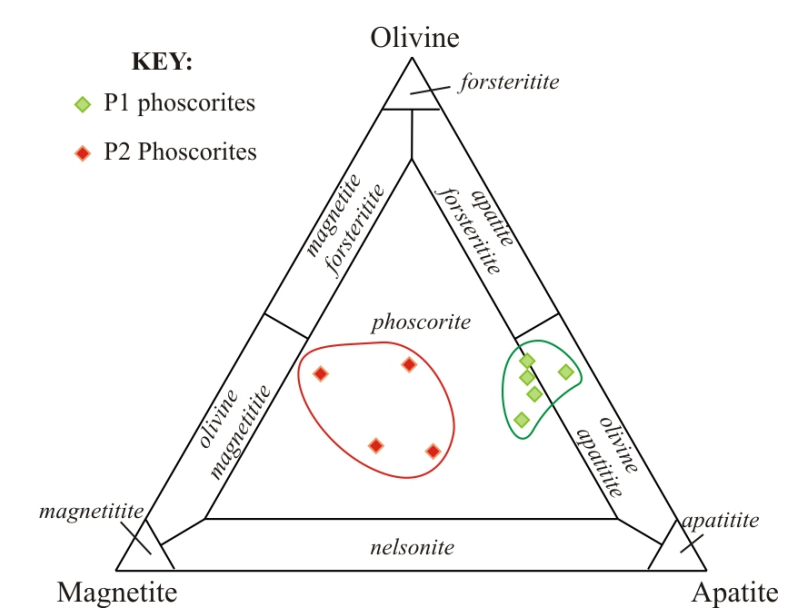

Figure 1 - Classification scheme for phoscorites adapted from Yegorov (1993).

In P1 phoscorites (Fig. 2a), olivine occur as subhedral to anhedral large grains, with abundant inclusions that mark growth lines. Olivine may also occur as inclusion-free small anhedral crystals. Phlogopite occurs as well developed euhedral lamellae, texturally simillar to typical phlogopites from Salitre bebedourites(Barbosa et al., 2008), such as coarse grain size and dark green - orange pleochroism with normal absorption directions. Often, slightly deformed lamellae indicates the movement of partially crystallized magma. Magnetite contains rare to abundant ilmenite exsolution lamellae. Sulfides are anhedral disseminated grains.

P2 phoscorites are composed of roughly equal proportions of olivine, apatite, and magnetite (Fig. 2b), and contains significant carbonate. Acessories are phlogopite, tetraferriphlogopite, and pyrochlore. These rocks vary from fine- to coarse-grained, often with microporphyritic texture, 


\section{$10^{\text {th }}$ International Kimberlite Conference, Bangalore - 2012}

where euhedral olivine, magnetite and apatite microphenocrysts with altered rims are set in a groundmass of subhedral to anhedral olivine, magnetite, apatite and pyrochlore, with interstitial carbonate.
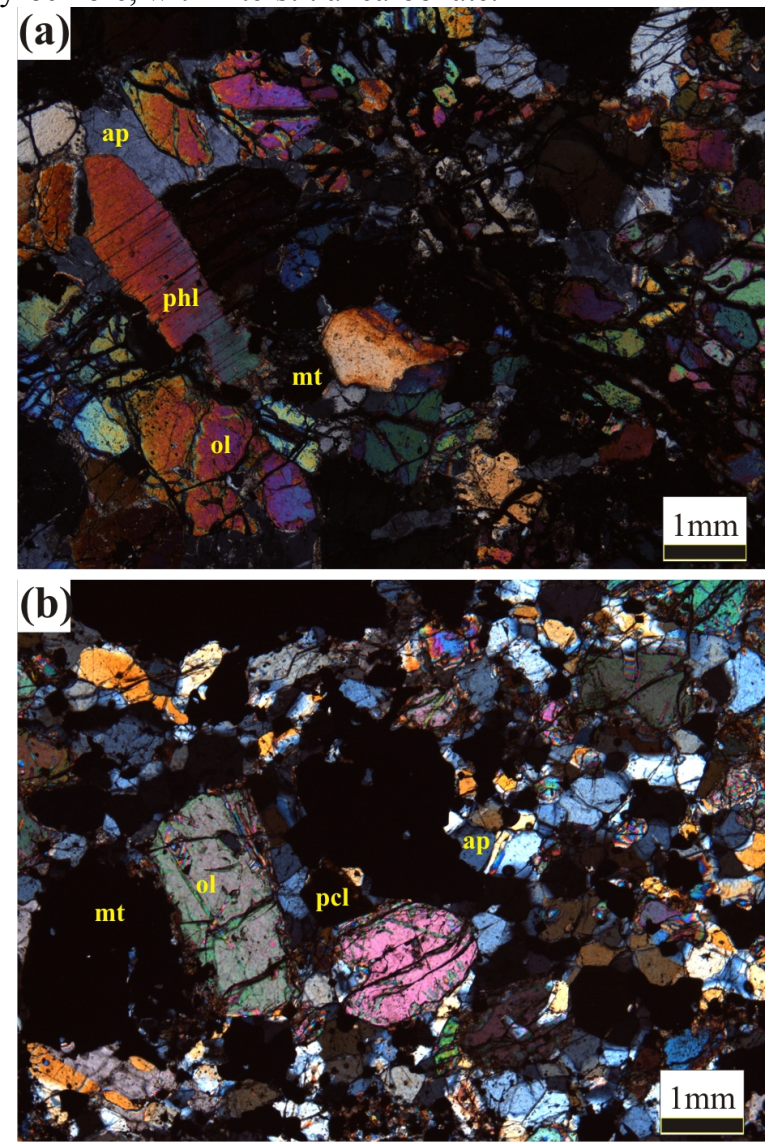

Figure 2 - a) P1 phoscorite, with equigranular texture and well developed phlogopite (nx); b) Microporphyritic texture from P2 phoscorite (nx).

Small euhedral red to yellow pyrochlore is scattered in the groundmass. Phlogopite is rare, as anhedral lamellae with tetra-ferriphlogopite rims. Magnetite is intercumulus, and does not contain visible ilmenite exsolution lamellae. It occurs as large poikilitic crystals that encompass groundmass crystals. Carbonate forms a centimetre-sized irregular pockets, which may have rims of elongated magnetite crystals , resembling a "comb-layering" texture, similar to that described by Cordeiro et al. (2010) in nelsonites from Catalão I.

\section{MINERAL CHEMISTRY}

The main mineral phases present in the Salitre phoscorites were analyzed by WDS using a CAMECA SX 50 electron microprobe at the University of Brasília, operating at $15 \mathrm{kV}$ and $20 \mathrm{nA}$.

Salitre phoscorites evolve from P1 to P2 with progressive decrease in whole-rock $\mathrm{MgO}$ contents, although specific minerals such as olivine, phlogopite and magnetite show increasing $\mathrm{MgO}$ contents in that direction.

Olivine from Salitre phoscorites is characterized by high $\mathrm{Mg} /(\mathrm{Mg}+\mathrm{Fe})$ ratio, contains significant amounts of $\mathrm{CaO}$ and $\mathrm{MnO}$, and is $\mathrm{NiO}$-poor, being therefore different from olivine in phoscorites and in silicate rocks (dunites, wehrlites) of alkaline-carbonatite complexes (e.g. Eriksson, 1989; Krasnova et al., 2004; Chakhmouradian \& Zaitsev, 2004). Olivine composition varies from chrysolite to forsterite. Forsterite (Fo) contents increase with decreasing whole-rock $\mathrm{MgO}$ (from P1 to P2, Fig. 3), indicating that the factors that control the partition of $\mathrm{MgO}$ and $\mathrm{FeO}$ between olivine and phoscoritic magmas are distinct from those in silicate magmas.

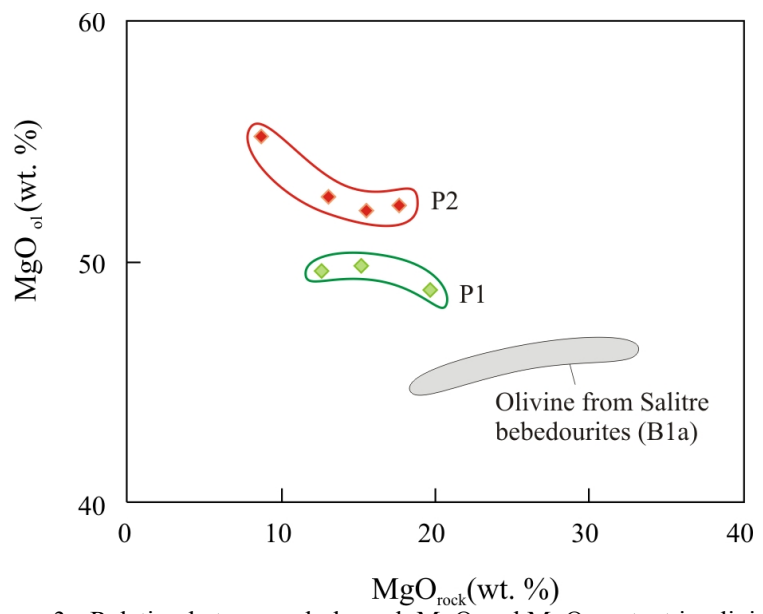

Figure 3 - Relation between whole-rock $\mathrm{MgO}$ and $\mathrm{MgO}$ content in olivines (analyses average).

Olivine from $\mathrm{P} 1$ are richer in $\mathrm{CaO}$ and $\mathrm{MnO}$ than those from $\mathrm{P} 2$, and their contents decrease with increasing Fo content from $\mathrm{P} 1$ to $\mathrm{P} 2$. NiO content is very small and does not correlate with Fo content in olivines, as observed in other carbonatite complexes (e.g. Eriksson, 1989; Krasnova et al., 2004; Chakhmouradian \& Zaitsev, 2004). The low Ni content in olivines from phoscorites may be associated to the removal of $\mathrm{Ni}$ from the system by early fractionation of Ni-rich olivine from a silicate parental magma or, alternatively, by Ni removal in an immiscible sulfide liquid, as proposed by Duke \& Naldrett (1978) for komatiite magmas.

Phlogopite varies along the phlogopite-tetra-ferriphlogopite series through Al depletion from P1 to P2 (Fig. 4), which is in contrast with the evolution of phlogopite from Salitre silicate rocks. $\mathrm{P} 1$ phlogopite is aluminous and may be Barich, due to the coupled $\mathrm{K}+\mathrm{Si}=\mathrm{Ba}+\mathrm{Al}$ substitution. $\mathrm{P} 2$ phlogopite crystals typically have Al-rich cores and Al-poor rims, in sharp contact. Similarly to olivine, the phlogopite from more evolved $\mathrm{P} 2$ phoscorites has higher $\mathrm{MgO}$ contents than $\mathrm{P} 1$ phlogopites. $\mathrm{MgO}$ variation in phlogopites from 


\section{$10^{\text {th }}$ International Kimberlite Conference, Bangalore - 2012}

phoscoritic rocks has a restricted range, and is independent from the whole-rock $\mathrm{MgO}$.

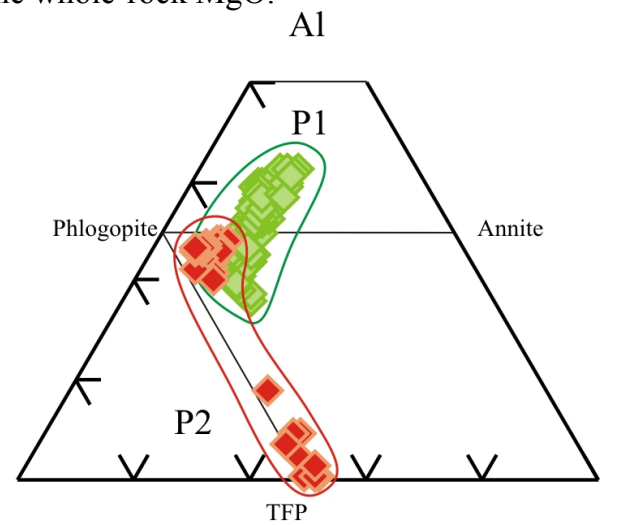

$\mathrm{Mg}$

$\mathrm{Fe}^{2+}+\mathrm{Fe}^{3+}$

Figure $4-\mathrm{Al}-\mathrm{Mg}-\mathrm{Fe}^{2+}+\mathrm{Fe}^{3+}$ diagram, for classification of phlogopites from Salitre phoscorites.

Magnetite shows little chemical variation, with higher $\mathrm{TiO}_{2}$ concentrations in $\mathrm{P} 1$, and higher $\mathrm{Al}_{2} \mathrm{O}_{3}$ in $\mathrm{P} 2$. The composition and chemical variations of magnetite from Salitre phoscorites is consistent with the described in the literature for other carbonatite complexes, i.e. close to the ideal end-member $\mathrm{Fe}_{3} \mathrm{O}_{4}$, with limited $\mathrm{Ti}$ and $\mathrm{Al}$ solid solutions (Eriksson, 1989; Krasnova et al., 2004; Lee et al., 2004; Karchevsky \& Moutte, 2004). Magnetite from phoscorites is richer in $\mathrm{MgO}$ than that from Salitre bebedourite. $\mathrm{MgO}$ content in magnetite increases from P1 to $\mathrm{P} 2$, similarly to what happens in olivine and phlogopite. $\mathrm{TiO}_{2}$ content in $\mathrm{P} 1$ magnetites varies widely, whereas $\mathrm{P} 2$ magnetites have lower $\mathrm{Ti}$ and a restricted compositional range. $\mathrm{Al}_{2} \mathrm{O}_{3}$ contents in $\mathrm{P} 1$ magnetites are very low, increasing significantly in $\mathrm{P} 2$, following the variation of $\mathrm{MgO}$ content. $\mathrm{MnO}$ increases in magnetite in the sequence P1-P2. All analyzed samples magnetites contain insignificant $\mathrm{NiO}$ and $\mathrm{Cr}_{2} \mathrm{O}_{3}$, mostly below detection limits.

Chemical variation of apatite is minimal, mostly through a restricted $\mathrm{Ca}+\mathrm{P}=\mathrm{Si}+\mathrm{ETR}$ substitution, which becomes less effective from P1 to P2. Apatite from Salitre phoscorites have similar to other examples in the literature (e.g Lee et al., 2004; Krasnova et al. 2004; Karchevsky \& Moutte, 2004), i. e, close to the ideal chemical composition, with restricted solid solutions. The analysed grains have low $\mathrm{SiO}_{2}, \mathrm{FeO}, \mathrm{MgO}, \mathrm{SO}_{3}$ and $\mathrm{BaO}$ contents, with little variation in $\mathrm{SrO} . \mathrm{Cl}$ and $\mathrm{Na}_{2} \mathrm{O}$ are below detection limits. The main compositional variation occurs in the $\mathrm{REE}\left(\mathrm{La}_{2} \mathrm{O}_{3}\right.$ e $\mathrm{Ce}_{2} \mathrm{O}_{3}$ ), whereby apatites from $\mathrm{P} 1$ are slightly richer in REE than apatites from $\mathrm{P} 2$ with a little composition overlap. The $\mathrm{Ca}^{2+}+\mathrm{P}^{5+}=\mathrm{ETR}^{3+}+\mathrm{Si}^{4+}$ substitution (Hogarth, 1989) is relevant, with the analyses aligned in a negative $1: 1$ correlation. $\mathrm{Si}+\mathrm{REE}$ decrease from $\mathrm{P} 1$ to $\mathrm{P} 2$, consistent with the core-rim relationships observed in most individual grains.
Pyrochlore in Salitre phoscorites is restricted to P2. In terms of $\mathrm{Nb}_{2} \mathrm{O}_{5}, \mathrm{TiO}_{2}$ and $\mathrm{Ta}_{2} \mathrm{O}_{5}$, the analysed grains belong to the pyrochlore sub-group, and contain remarkably higher $\mathrm{Ta}_{2} \mathrm{O}_{5}$ than pyrochlores from Salitre carbonatites (Barbosa et al., 2012). When compared with pyrochlores from phoscorites of Sokli (Lee et al., 2006) and Catalão I (Cordeiro et al., 2011) P2 pyrochlores have a similar composition to the Sokli early-stages (P2) phoscorite, but with lower $\mathrm{Ta}_{2} \mathrm{O}_{5}$ contents. Pyrochlore from Catalão I nelsonites is $\mathrm{Ta}_{2} \mathrm{O}_{5^{-}}$ poor, suggesting a less evolved character for Salitre phoscorites. Pyrochlore in $\mathrm{P} 2$ phoscorites is also rich in $\mathrm{UO}_{2}, \mathrm{Ta}_{2} \mathrm{O}_{5}, \mathrm{ThO}_{2}$, and $\mathrm{FeO}$, with variable LREE contents. Minor constituents comprise $\mathrm{MnO}, \mathrm{K}_{2} \mathrm{O}, \mathrm{ZnO}$ and $\mathrm{SrO}$. $\mathrm{BaO}$ is below detection limits in all analysed grains. The absence of $\mathrm{BaO}$ and the very low $\mathrm{SrO}$ contents suggest that pyrochlore was not affected by secondary processes, such as hydrotermalism or weathering, and their composition is representative for magmatic pyrochlores from Salitre I.

\section{WHOLE-ROCK TRACE ELEMENTS}

Phocorites cover a large compositional range in both major and trace elements. Krasnova et al. (2004) correlate the variation of major elemens to the presence of specific minerals. Most of the studied Salitre phoscorites represent cumulates, which difficults the use of differentiation indices. Regardless of compositional overlap, whole-rock geochemistry shows a $\mathrm{MgO}$ decrease from $\mathrm{P} 1$ to $\mathrm{P} 2$, and a divergent evolution path from silicate rocks in a $\mathrm{MgO} \times$ $\mathrm{SiO}_{2}$ diagram (Fig. 5), suggesting that these two rock types may be related through a silicate-phosphate liquid immiscibility event. $\mathrm{P}_{2} \mathrm{O}_{5}$ decreases from $\mathrm{P} 1$ to $\mathrm{P} 2$, suggesting that phoscorite magma evolves by apatite fractionation, producing a carbonate-rich residue which often grades into carbonatite.

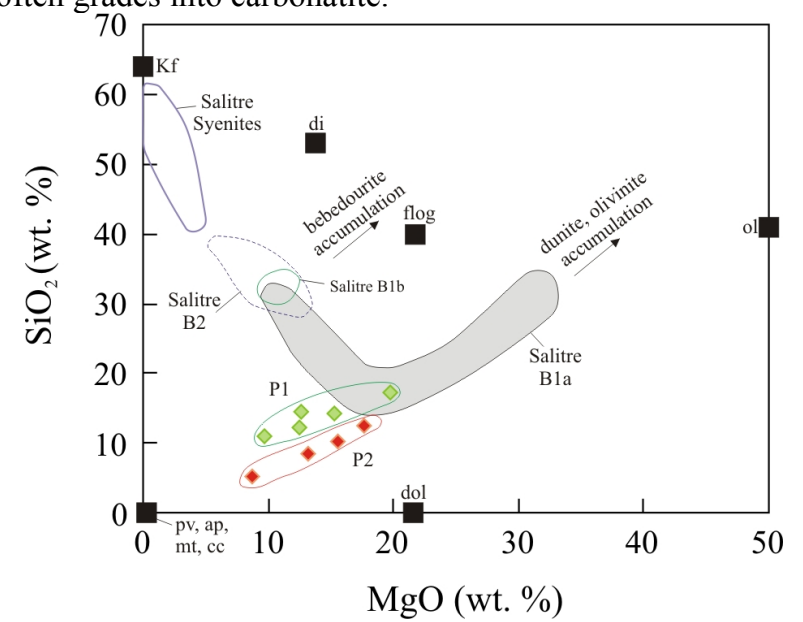

Figure 5 - Evolution of phoscorite series and related silicate rocks (Barbosa et al., 2008) from Salitre I complex.

In terms of trace elements, phoscorites tipically contain low $\mathrm{Cr}$ and $\mathrm{Ni}$, and high $\mathrm{Zr}, \mathrm{Nb}, \mathrm{Ta}, \mathrm{Hf}, \mathrm{Th}, \mathrm{U}$, and $\mathrm{Cu}$ (Krasnova et al., 2004). Salitre phoscorites have low $\mathrm{Cr}$ and 


\section{$10^{\text {th }}$ International Kimberlite Conference, Bangalore - 2012}

$\mathrm{Ni}$ contents. $\mathrm{Ba}$ and $\mathrm{Sr}$ are intermediate between Salitre bebedourites and carbonatites.

P1 phoscorites contain the lowest $\mathrm{U}$ and Th contents, and the highest $\mathrm{Cu}$, the latter related to the presence of sulfides. P2 phoscorites have very low $\mathrm{Cu}$ and a wide $\mathrm{U}$ and $\mathrm{Th}$ compositional range. Pyrochlore-free phoscorites have low $\mathrm{U}$ and $\mathrm{Th}$, although pyrochlore-bearing phoscorites have the highest $U$ and Th concentrations. This indicates that, as for many major elements, these element contents are controlled by the modal proportions of specific minerals.

A chondrite-normalized trace-element diagram (Fig. 6a) shows that all phoscorite groups have negative anomalies at $\mathrm{Rb}, \mathrm{K}, \mathrm{Sr}$, and Ti. P1 and P2 phoscorites have similar behavior patterns, with more pronounced anomalies in $\mathrm{P} 2$. Inversion of $\mathrm{Nb} / \mathrm{Ta}$ ratios for each phoscorite group may be related to silicate-carbonatite liquid immiscibility (e.g. Veksler et al., 1998, Brod, 1999), or, alternatively, to $\mathrm{Nb}$ or Ta removal in some mineral phase (e.g. Chackmouradian, 2006). $\mathrm{Zr} / \mathrm{Hf}$ ratio is constant for both $\mathrm{P} 1$ and $\mathrm{P} 2$, and independent of differenciation events, except in the more envolved terms.
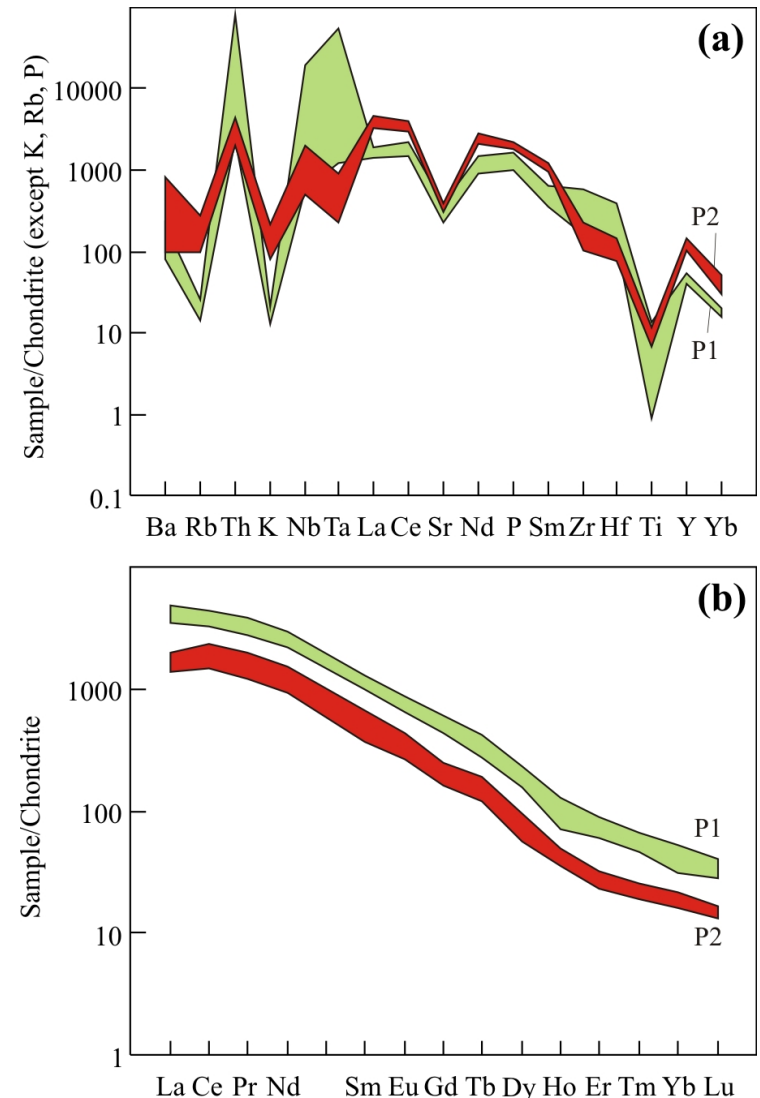

Figure 6 - a) Chondrite-normalized (Thompson et al., 1984) trace-element diagram; b) Chondrite-normalized (Boynton, 1984) REE diagram.
Both phoscorite units show strongly LREE/HREE fractionated parallel patterns, but $\sum$ REE decreases from P1 to P2 (Fig 6b).

Carbon and oxygen stable isotopes in carbonates show that Salitre phoscorites crystallized from mantle-derived magmas. Figure 7 show that the range of $\delta^{13} \mathrm{C}_{\mathrm{PDB}}$ variation is smaller than that of $\delta^{18} \mathrm{O}_{\text {SMOW, }}$, which may be connected with subtle post-magmatic alteration through interaction with low-temperature fluids. This is slightly more pronounced in P1, probably because these rocks formed at an earlier stage.

Sr-Nd isotopes of Salitre phoscorites agree well with the isotopic composition of the rest of the APIP. Sr isotopic ratios are nearly constant, whereas $\mathrm{Nd}$ isotopes vary in a wider range.

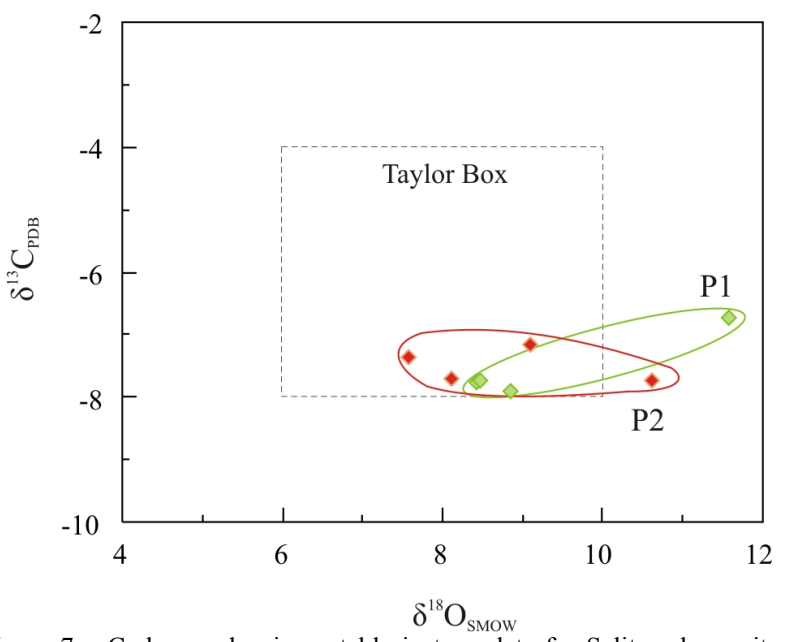

Figure 7 - Carbon and oxigen stable isotope data for Salitre phoscorites. Dashed field are isotopic composition of primary carbonatite (Taylor Box).

\section{CONCLUSIONS}

Textural, mineral chemistry, whole-rock geochemistry, and isotopic evidence show that Salitre phoscorites are mantlederived magmas. Although in some cases these rocks may be the product of the accumulation of olivine, apatite and magnetite from carbonatitic liquids, in others phoscorites form discordant bodies (dykes), that suggest the emplacement of a phoscoritic magma. Such liquids were probably generated by liquid immiscibility, from a bebedouritic and/or carbonatitic magma, and evolved by olivine, apatite and magnetite crystal fractionation, with residual carbonate enrichment.

\section{ACKNOWLEDGEMENTS}

This work was supported by CNPq (Brazilian Council for Research and Development) and University of Brasília.

\section{REFERENCES}




\section{$10^{\text {th }}$ International Kimberlite Conference, Bangalore - 2012}

Barbosa, E.S.R., Junqueira-Brod, T. C., Brod, J. A., Dantas, E.L., 2008. Petrology of bebedourites from the Salitre phoscorite-carbonatite complex, Brazil. In: 9th International Kimberlite Conference, 2008, Frankfurt. Extended Abstracts. Frankfurt : COSIS - Copernicus Systems, 2008. p. 9IKC-A-00332.

Barbosa, ESR, Brod, JA, Junqueira-Brod, TC, Cordeiro, PFO, Dantas, EL, Santos, RV. 2012. Mineralogy and petrology of the Salitre I phoscorite-carbonatite-alkaline complex, Brazil. In: 10th International Kimberlite Conference, 2012, Bangalore. Extended Abstracts. Bangalore: p. 10IKC-293.

Boynton, W.V., 1984. Cosmochemistry of the rare earth elements: meteorite studies. In: Henderson, P. (Editor), Rare Earth Element Geochemistry. Elsevier, Amsterdam, pp. 63-114.

Brod J.A., 1999. Petrology and geochemistry of the Tapira alkaline complex, Minas Gerais State, Brazil. University of Durham, UK (PhD thesis).

Chakmouradian A. R., Zaitsev A. N., 2004. Afrikanda: An association of ultramafic, alkaline and alkali-silica-rich carbonatitic rocks from mantle-derived melts. In: Phoscorites and Carbonatites from Mantle to Mine: the Key Example of the Kola Alkaline Province (F. Wall and A.N. Zaitsev, editors) Mineralogical Society Series, pp 247-292.

Chakmouradian A. R., Williams C. T. 2004. Mineralogy of high-field-strenght elements ( $\mathrm{Ti}, \mathrm{Nb}, \mathrm{Zr}, \mathrm{Ta}, \mathrm{Hf}$ ) in phoscoritic and carbonatitic rocks of the Kola Peninsula, Russia. In: Phoscorites and Carbonatites from Mantle to Mine: the Key Example of the Kola Alkaline Province (F. Wall and A.N. Zaitsev, editors) Mineralogical Society Series, pp 293-340.

Chakmouradian A. R., 2006. High-field-strength elements in carbonatitic rocks: Geochemistry, crystal chemistry and significance for constraining the sources of carbonatites. Chemical Geology 235: 138-160.

Cordeiro, P.F.O., Brod, J.A., Santos, R.V., Dantas, E.L., Oliveira, C.G., Barbosa, E.S.R.B. 2010. Stable (C,O) and radiogenic $(\mathrm{Sr}, \mathrm{Nd})$ isotopes of carbonates as indicators of magmatic and post-magmatic processes of phoscorite-series rocks and carbonatites from Catalão I complex, central Brazil. Contributions to Mineralogy and Petrology 161: 451-464.

Cordeiro, P.F.O., Brod, J.A., Palmieri, M., Oliveira, C.G., Barbosa, E.S.R., Santos, R.V., Gaspar, J.C., Assis, L.C. 2011. The Catalão I niobium deposit, central Brazil: resources, geology and pyrochlore chemistry. Ore Geology Reviews 41: 112-121.
Duke J. M., Naldrett A.J., 1978. A numerical model of the fractionation of olivine and molten sulfide from komatiite magma. Earth and Planetary Science Letters 39: 255-266.

Eriksson S.C., 1989. Phalaborwa: A saga of magmatism, metassomatism and miscibility. In K. Bell (Ed.) Carbonatites: genesis and evolution. London, Unwin Hyman, 221-254.

Hogarth, D. D., 1989. Pyrochlore, apatite and amphibole: distinctive minerals in carbonatite. In K. Bell (Ed.) Carbonatites: genesis and evolution. London, Unwin Hyman, 105-148.

Karchevsky, P.I., Moutte, J., 2004. The phoscoritecarbonatite complex of Vuoriyarvi, northern Karelia. In: Phoscorites and Carbonatites from Mantle to Mine: the Key Example of the Kola Alkaline Province (F. Wall and A.N. Zaitsev, editors) Mineralogical Society Series, pp 163-169.

Krasnova, N.I., Petrov, T.G., Balaganskaya, E.G., Garcia, D., Moutte, D., Zaitsev, A.N. and Wall, F. 2004. Introduction to phoscorites: occurrence, composition, nomenclature and petrogenesis. In: Phoscorites and Carbonatites from Mantle to Mine: the Key Example of the Kola Alkaline Province (F. Wall and A.N. Zaitsev, editors) Mineralogical Society Series, pp 45-79.

Lee, M.J., Garcia, D., Moutte, J., Williams, C.T. and Wall, F., 2004, Carbonatites and phoscorites from the Sokli complex, Finland. In: Phoscorites and Carbonatites from Mantle to Mine: the Key Example of the Kola Alkaline Province (F. Wall and A.N. Zaitsev, editors) Mineralogical Society Series. p. 133-162.

Lee, M.J., Lee, J.I., Garcia, D., Moutte, J., Williams, C.T., Wall, F., Kim, Y., 2006. Pyrochlore chemistry from the Sokli phoscorite-carbonatite complex, Finland: Implications for the genesis of phoscorite and carbonatite association: Geochemical Journal 40: 1-13.

Thompson, R.N., Morrison, M.A., Hendry, G.L., Parry, S.J., 1984. An assessment of the relative roles of crust and mantle in magma genesis: an elemental approach. Philosophical Transactions of the Royal Society of London A310: 549-590.

Veksler, I. V., Petibon, C., Jenner, G. A., Dorfman, A. M. and Dingwell, D. B., 1998. Trace element partitioning in immiscible silicate-carbonate liquid systems: an initial experimental study using a centrifuge autoclave. Journal of Petrology 39: 2095-2104.

Yegorov, L.S., 1993. Phoscorites of the Maymecha-Kotuy ijolite-carbonatite association. International Geology Review 35: 346-358. 